\title{
MEETING DIVERSITY IN ESL CLASSROOM: A PEDAGOGICAL MODEL FOR A GLOBALIZED MILIEU
}

\author{
Umara Shaheen ${ }^{1}$, Muhammad Shaban Rafi ${ }^{1}$, Shazia Aziz ${ }^{3}$, Noor-Ul-Ain ${ }^{4}$ \\ ${ }^{1}$ COMSATS University Islamabad, Lahore Campus, Pakistan \\ ${ }^{2}$ University of Management and Technology, Lahore, Pakistan \\ E-Mail: ushaheen@cuilahore.edu.pk,E-Mail:shaban@umt.edu.pk, \\ shazia.aziz@cuilahore.edu.pk,noorulain@cuilahore.edu.pk,
}

\begin{abstract}
Globalization demands dynamism in English as a Second Language (ESL) pedagogy to address the needs of students from diverse cultural, educational and linguistic backgrounds. Students hailing from different countries with varied levels of English proficiency present a serious challenge to instructors. The challenge to meet the needs of diverse students from Afghanistan and Pakistan, for instance, within the same teaching faculty, prompted this study. It attempts to explore Afghan and Pakistani students' expectations of the first module of English introduced at undergraduate level, i.e., English Comprehension and Composition (ECC) at a Pakistani university, by applying the Expectancy Disconfirmation Model of Satisfaction (Oliver 2015,120). Students' expectations have been a neglected area of research despite being a significant factor in behavior and performance. This study aims to find out how far the Pakistani and Afghan students' expectations have been met with Negative Disconfirmation (non-fulfillment), Zero Disconfirmation (fulfillment) or Positive Disconfirmation (enhanced fulfillment). The findings reveal that the Afghan students were enrolled in the Pakistani university as a result of a mutual agreement between the Pakistani and Afghan governments under the Higher Education Commission (HEC)scholarship "Award of 3000 Scholarships to Students from Afghanistan under the Prime Minister's Directive" had concerns with the advanced level grammar and reading exercises, while Pakistani students complained about insufficient class time, consecutive lectures and lack of adequate practice provided in the classroom. The study suggests a pedagogical framework for the students focusing on Contextualized Task Based Language Teaching (CTBLT) method in combination with Input-oriented approach for the desired academic outputmentioned in the objectives of the course/module.
\end{abstract}

Key words: ELT, negative disconfirmation, zero disconfirmation, positive disconfirmation, contextualized task-based language teaching

\section{INTRODUCTION}

Globalization has brought diversity to classrooms and educational institutions which present instructors with enormous challenges of having to deal with culturally and linguistically diverse students as opposed to the monocultural and monolingual groups they may have been accustomed to in the past. The development of an effective English language pedagogy for students depends on recognizing, acknowledging and responding to the needs and expectations of diverse English language learners. Generally, learning 
outcomes can be affected by various social and psychological factors such as gender, family stress, communicative competence, desire for skill improvement and how challenging tasks are (Mushtaq\& Khan 2012, 18; Wang \& Chen 2015,25).

Previously, most research has been confined to the exploration of university students' expectations of various academic programs with a focus on self-regulated leaning (Hassel \&Ridout 2018; Money et al. 2017; Paechter, Maier \&Macher2009), vocational and utilitarian orientations (Lehmann 2008) and interactive lectures with group-based activities (Sander et. al. 2000), but a comparison of ESL students' expectations, especially those from diverse background, remains underexplored despite being an important factor in Second Language Acquisition (SLA). Moreover, so far the researchers' focus has been on motivation in SLA (Dörnyei 2005; Iwaniec 2018; Lasagabaster 2011; Masgoret and Gardner 2003; Ngo, Spooner-Lane \&Mergler 2017; Sugitaa\& Takeuchi 2011; Tremblay, Gardner \&Heipal2000), or on the expectations of students of Teaching English to Speakers of Other Languages (TESOL) programs (Bordia et. al. 2006, 2011) or English Enhancement Courses (Lobo \& Gurney 2014) from which the current study differs as it compares the host country as well as international students' expectations from a mandatory English course which is taught by the host country's instructors.

As international students' expectations have a significant impact on their performance, Goldschmidt \& Seifried (2008) explored immigrant students' expectations of their college and their career goals. They found that non-fulfillment of students' expectations regarding their academic performance resulted in disappointment (31). Hence, expectation fulfillment or nonfulfillment can lead to satisfaction or disappointment, thus affecting their motivation and performance, as contended by Bordia et.al. (2006) and retention, as asserted by Lobo \& Gurney (2014).

The current study aims to explore the differences between Pakistani and Afghan students' expectations from the "English Comprehension and Composition" (ECC) course by applying the Expectancy Disconfirmation Model (Oliver 2015). Owing to the limited opportunities available in Afghanistan in the fields of medicine and engineering, Afghan students have been admitted to HEC (Higher Education Commission) accredited Pakistani universities as a result of a mutual agreement between the Pakistani and Afghan governments' "Award of 3000 Scholarships to Students from Afghanistan under the Prime Minister's Directive". The present study was carried out at COMSATS University Islamabad, Lahore, Pakistan, where 115 Afghan students were enrolled in different undergraduate programs offered by different departments in the first step of this agreement in the fall 2016. Like other higher education institutes and universities in Pakistan, students enrolled in all undergraduate programs have to study different modules of English as compulsory courses taught by the same teaching staff in the Department of Humanities at COMSATS University Islamabad, Lahore, Pakistan. This study compared Afghan and Pakistani students because the same teaching staff taught these groups of Pakistani and Afghan students from two distinct cultural and linguistic backgrounds to find out whether the English language teaching addresses the needs of both groups studying in the same classroom and to suggest a possible framework to cater for diverse students. The study takes into account the perspectives of students as well as instructors about whether the course fulfilled the Afghan and Pakistani students' expectations. The study is a significant endeavor to highlight the strengths and weaknesses of the ECC course which can help instructors, syllabus designers and institutes to make amendments to the course and suggest alternative teaching practices to meet the needs of students from different academic and cultural backgrounds learning a second language in one group. 
Before comparing Afghan students' expectations and satisfaction level with those of Pakistani students, a brief overview of the English Language Learning system in Afghanistan and Pakistan, the ECC course and Expectancy Disconfirmation Model (Oliver 2015) is presented in"Expectancy disconfirmation model of satisfaction"after the next section below.

\subsection{English Language Learning in Pakistan and Afghanistan}

English, one of the official languages in Pakistan, is associated with power, prestige and success for Pakistani students (Rahman 2003, 01) and enjoys a privileged status due to the patronage of elites as a symbol of modernization (Shah \&Afsar 2017, 160). According to Jalal (2004) and Jillani (2009), most Pakistani students are taught English as a compulsory subject from their first grade till their advanced degree (as cited in Nawaz, Amin \&Tatla 2015, 104). Likewise, in Afghanistan, English Language learning is considered a gateway to individual and collective success (Zaynal, Mushtaq \& Kazimi 2011). However, the Afghan education system is affected by the precarious socio-political situation of one of the most troubled countries in the world, six million of whose citizens live as refugees in many countries, including Pakistan, Iran, Russia and Canada (Nazar 2012, 01).

A study conducted in Canada of the English language learning experiences of Afghan immigrant high school students revealed that one of the challenges they faced was difficulty in listening and speaking English, which resulted in them failing tests and exams (Nazar 2012, 36), because the main focus of their ELT in Afghanistan had been grammar, lexicon and structures (Zaynal, et al. 2011, g). Nazar $(2012,40)$ found that despite this obstacle, the students expressed a strong desire to make the best of their opportunities in learning the language, both within and outside their formal school environment, as they were aware of the importance of English for their survival in any academic and professional fields.

On the other hand, despite being taught English as a compulsory subject from grade one, the factors hindering students' learning of English were ineffective teaching methodology, outdated syllabi, flawed examination systems, vague educational policies, lack of provision of modern teaching technology in the public sector institutions and not enough proficient English teaching instructors (Nawaz et al. 2015, 104). In contrast to Afghanistan, there are a number of opportunities available in the fields of health and engineering education in Pakistan; therefore, the Afghan students were provided with scholarships and admitted to HEC accredited Pakistani universities. Thus, 300 Afghan students were admitted to medical universities and around 300 to engineering universities in Pakistan, as a result of a mutual agreement between the governments of Pakistan and Afghanistan (Raza, February 09, 2017).

\subsection{Expectancy Disconfirmation Model of Satisfaction}

The analysis of consumer expectations and satisfaction has been a subject of great interest in Consumer Psychology. Consumers come across a number of advertisements claiming to meet their expectations, provide more than they expected, so exceed their expectations (Oliver 2015, 96). Just like consumers of products and services, students can also be considered as customers who spend a great deal of money to acquire education to meet their needs and expectations and eventually achieve their goals. This study conducted a comparative survey of the expectations of Afghan and Pakistani students to evaluate how far their expectations had been confirmed or disconfirmed concerning the 
English course taught in the $1^{\text {st }}$ semester of an undergraduate program at a Pakistani university situated in Lahore.

The Expectancy Disconfirmation Model of Satisfaction was introduced by Richard Oliver in 1977 and further developed in a paper in 1980 and the $1^{\text {st }}$ edition (1997) and 2nd edition (2010, 2013, 2014 \& 2015) of his book "Satisfaction: A Behavioural Perspective on Consumer Psychology." The current study was inspired by the research article Student Expectations of TESOL Programs: Student and Instructor Perspectives (Bordia, Wales, Pittam \& Gallois 2006) which applied the Expectancy Disconfirmation Model (1997) to explore how far the expectations of multicultural students of TESOL studying in Australia were satisfied / confirmed / or disconfirmed. The current study applied the modified model (2015) (see Figure 1.1), because it illustrates the relationship between expectation, performance and expectation disconfirmation more comprehensively.

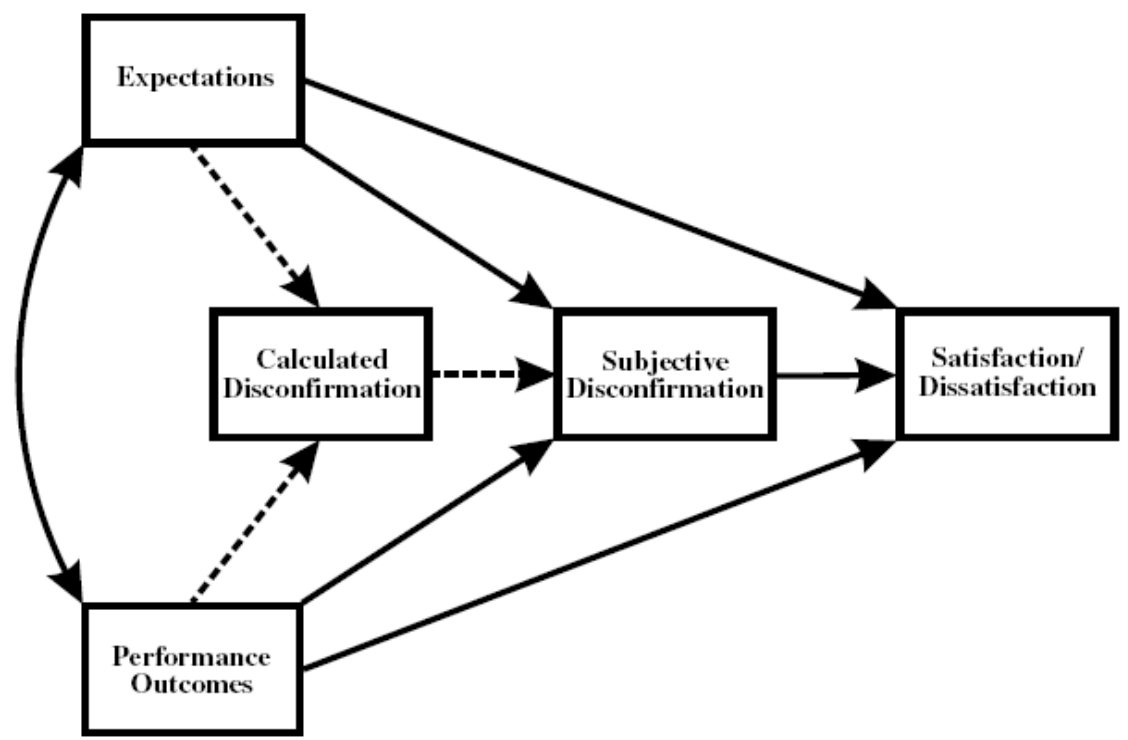

Fig. 1 Expectancy disconfirmation with performance model (Oliver 2015, 120)

Before purchasing products, buyers "first generate an expected level of service" and then form perceptions about the product on the basis of performance outcomes, which can lead to the disconfirmation of expectations if outcomes are not as expected (Song et al. 2016, 218). However, the concept of disconfirmation in the Expectancy Disconfirmation Model (Oliver 2015, 120) (see Figure 1.1) refers to a 'discrepancy from the standard' which can be positive or negative. Negative disconfirmation occurs when performance does not meet the standard or it falls short of expectations, while positive disconfirmation takes place when performance exceeds expectations. When performance meets the standard or expectations, this is called zero disconfirmation or a confirmation of expectations (Oliver 2015,100 ). Since the present study is a qualitative study, it does not take into account 'calculated disconfirmation' because it refers to "numerical comparisons (e.g. subtracting an expectation score from a performance score - known as a 'gap') in a product or service evaluation" (Oliver 2015,102) which is outside the scope of this study. 
Bordia et. al. (2006) analysed students' and instructors' responses to interviews conducted to shed light on the "nature of expectations, factors causing expectations and effects of expectation fulfillment (or lack of it)" (Bordia et. al. 2006, 4.1). The findings show that fulfillment of expectations can enhance student motivation in TESOL. The students' expectations reflect their immediate, as well as future goals. Participants knew that they needed to acquire listening, speaking and presentation skills to survive in the academic and professional fields (Bordia et. al. 2006, 4.8). As for instructors' perspectives about students' expectations, Bordia's study indicated that instructors also believed that students come with too many expectations to be fulfilled to develop a positive learning environment. Instructors also showed their concern about the modifications to the course outline to cater for the societal and professional needs of the students (Bordia et. al. 2006, 4.17). The study, though, was a significant endeavour to evaluate multicultural TESOL students' expectations, but it did not compare the expectations of cohorts of students with two different cultural backgrounds. Moreover, the students in that context were learning English for professional reasons while, in the current study, the expectations of the students studying the foundation English course, a pre-requisite for other English courses they are required to study, were analysed. This study analysed the expectations of Pakistani and Afghan students who studied an ECC course in the fall 2016 to find out the similarities and differences between their expectations and what they experienced, which can help instructors and course coordinators to address the issues faced by these students and inform other instructors around the world embarking upon teaching any second language learners coming from different cultural backgrounds.

\section{RESEARCH QUESTIONS}

1. What expectations do the Afghan and Pakistan students have about the content and methodology used in the ECC course?

a) How far are the expectations of both groups similar?

b) To what extent do their expectations differ?

2. What factors cause zero, positive or negative disconfirmation of Afghan and Pakistani students' expectations?

3. What effects do zero, positive and negative disconfirmation of expectations have on Pakistani and Afghan students' motivation?

\section{METHOD AND MATERIALS}

Interview protocols with open-ended interview questions were adapted from the protocols used in Bordia et. al.'s study keeping in mind the nature of the English module and participants' cultural backgrounds to analyse students' and instructors' perspectives concerning students' expectations regarding the following: the content and methodology of teaching; the factors that shaped their expectations; similarities and differences between the current teaching methods and those used in the previous twelve academic years of students' lives; and the impact of the students' satisfaction and dissatisfaction with their motivation level. A few questions were modified to facilitate students' and instructors' understanding e.g. the word "variables" was replaced with 'factors' which affect students' expectations. A question about comparing the previous (last twelve academic years) and present teaching methods was added because previous ways of teaching/course delivery play a pivotal role in shaping students' expectations. 
The interviews were conducted in English using a semi-structured questionnaire (see appendix-https://docs.google.com/document/d/1f56jf8Z8mxH4S7texDeVIkggJ_ YXB461qmhsv19NhXg/edit?usp=sharing). The interview questions were not shared or distributed amongst the participants beforehand. The students were asked to respond to the questions with respect to the ECC course they were studying. Semi-structured interviews of two instructors teaching the cohorts of study were conducted to find out their perspective about their students' expectations.

\subsection{Participants}

For the present study, a purposive sample of 10 Afghan students and 10 Pakistani students (10 males and 10 females; av. age $=20$ yrs.) was selected from the two sections of the Department of Electrical Engineering at COMSATS University Islamabad, Lahore campus. Each section was comprised of 30 students (two groups of 15 Pakistani and Afghan students each); therefore, the representative sample of 10 students from each section was selected. The interviews conducted at the end of the session to find out their level of expectation disconfirmation or confirmation in the light of which a pedagogical framework is developed for future instructors. The students were enrolled in the course English Comprehension and Composition (ECC). ECC is the foundation English course offered in the $1^{\text {st }}$ semester at the Pakistani university where the study was conducted. The course aims to enhance the English language proficiency of students, mainly focusing on grammar and the four skills of listening, reading, speaking and writing. The course contents include reading skill, basic grammar review, listening comprehension, speaking, presentation skills and essay writing. The activities adopted by the instructors are context-based grammar and vocabulary exercises, controlled and free writing, role play and reading activities based on interesting and amusing short stories. Evaluating the students' expectations of this course is important as it is the foundation course which prepares students for the subsequent English courses offered in the following semesters, so the results can inform instructors about the preferred methodology of teaching for upcoming modules.

\subsection{Instructors interviews}

A purposive sample of two instructors ( 1 female and 1 male; av. teaching experience = 7 years) was interviewed individually for the current study. Both instructors were teaching sections comprising Afghan and Pakistani students.

\section{ETHICAL CONSIDERATIONS}

As the current study required the participation of human respondents, certain ethical issues were addressed to ensure their consent and their privacy was maintained. The participants were informed that their interviews would be recorded and their permission was obtained. The consent of the students and instructors was sought by assuring them that the research study was conducted solely for academic purposes and the information gathered through the interviews would not be used for any other purpose and their names and personal information would be kept confidential and not disclosed. Only profile details relating to answering the research questions were needed. 


\section{PROCEDURE}

The students' and instructors' interviews were audio-taped and transcribed. Content analysis was used to analyse the students' and instructors' responses due to its effectiveness as a method to interpret the content of text and interviews as it systematically identifies, and codes themes (Hsieh \& Shannon 2005, 1278). The data collected through the interviews were manually coded and categorized and themes were developed on the basis of recurring ideas.

\section{RESULTS AND ANALYSIS}

Table 1 Students' expectations related to content and methodology

\begin{tabular}{|c|c|c|c|}
\hline $\begin{array}{c}\text { Afghan students content } \\
\text { related expectations }\end{array}$ & \begin{tabular}{|c|} 
Afghan students \\
teaching \\
methodology related \\
expectations \\
\end{tabular} & $\begin{array}{l}\text { Pakistani students } \\
\text { content related } \\
\text { expectations }\end{array}$ & $\begin{array}{l}\text { Pakistani students } \\
\text { teaching } \\
\text { methodology related } \\
\text { expectations } \\
\end{array}$ \\
\hline \begin{tabular}{|l|} 
Expectations to learn \\
the following skills: \\
- Reading (2) \\
- Writing (2) \\
- Listening \\
- Speaking and \\
presentation skills (4) \\
- Pronunciation (3) \\
- Vocabulary (2) \\
- Grammar (4) \\
- Sentence structure (1) \\
- Samples/notes/ \\
examples \\
- Giving examples (0) \\
- Start with basics (1) \\
- Presentation Skills1 \\
- Overall fluency (2) \\
- Integrated practice of \\
the language
\end{tabular} & \begin{tabular}{|l|} 
- Communicative \\
activities (3) \\
- Group work rather \\
than pair work (1) \\
- Structure of writing \\
(1) \\
- Individual writing \\
activities \\
- Group writing \\
activities based on \\
shared ideas \\
- Lecture method (2) \\
- Use of computers \\
\& multimedia, A/V \\
aids. (2) \\
- Generalized \\
expectations at the \\
onset of the course \\
(1) \\
- Expectations \\
regarding specific \\
skills at the onset \\
of the course \\
- Greater \\
expectations from \\
Pakistani \\
institutions than \\
from those in home \\
country
\end{tabular} & \begin{tabular}{|l} 
Expectations to learn \\
the following skills: \\
- Reading (1) \\
- Writing (2) \\
- Calligraphy (1) \\
- Listening \\
- Speaking and \\
presentations (4) \\
- Pronunciation (1) \\
- Vocabulary (1) \\
- Grammar (2) \\
- Sentence structure \\
(1) \\
- Samples/notes/ \\
example (2) \\
- Giving examples (1) \\
- Started with basics \\
- 1 ) \\
- Should listen to our \\
problems (1) \\
- Too much syllabus, \\
no revision time (3) \\
- International English \\
Language Testing \\
System (IELTS) \\
preparation \\
- Presentation Skills \\
- Overall fluency (1) \\
- Integrated practice of \\
the language (1) \\
- Overall content \\
\end{tabular} & $\begin{array}{l}\text { - Communicative } \\
\text { activities } \\
\text { - Group work rather } \\
\text { than pair work (1) } \\
\text { - Structure of writing } \\
\text { - Individual writing } \\
\text { activities } \\
\text { - Group writing } \\
\text { activities based on } \\
\text { shared ideas (1) } \\
\text { - More conceptual } \\
\text { than rote (1) } \\
\text { - Use of computers \& } \\
\text { multimedia, A/V } \\
\text { aids, (2) } \\
\text { - Generalized } \\
\text { expectations at the } \\
\text { onset of the course } \\
\text { - Expectations } \\
\text { regarding specific } \\
\text { skills at the onset of } \\
\text { the course }\end{array}$ \\
\hline
\end{tabular}




\subsection{Expectations related to content and methodology}

\subsubsection{Students' perspective}

Students' expectations investigated in this study pertained to two broad domains: content and teaching methodology. Table 1 shows the frequency of responses (in parenthesis) from Afghan and Pakistan students' interviews. Table 1 shows that out of the four English language skills, speaking skills with emphasis on presentation skills and pronunciation were the most expected areas of focus by the students of both nationalities. Three Afghan students expected to learn American pronunciation in class because, according to them, they were exposed to American pronunciation in their home country, but here in Pakistan, these Afghan students found out that they were taught British pronunciation.

As for Pakistani students, one Pakistani student said she "wanted to get native-like (British) fluency". Two participants from each group said that they expected this module would help improve their writing skills. Two Afghan and one Pakistani student expected their reading skills would also improve through this module.

Two students from each group expected multimedia, computers and audio-visual aids to be used more than they actually were in classes. Three Afghan students expected to be engaged in communicative tasks e.g. presentations and discussions, but time constraint did not allow this to happen frequently, except in two or three classes out of the total of 32. This contrasted with the views of two Afghan students, who said that they improved their pronunciation and speaking through class activities. Four Afghan and two Pakistani students said they expected to learn grammar and two Afghan and one Pakistani student expected to learn vocabulary. This difference suggests that since in Afghanistan, their focus was on grammar and vocabulary, as mentioned by the Afghan students, they expected to learn English along the same lines in Pakistan. Overall, the Afghan students linked their need to learn and improve English language with their goal to study abroad in future for higher studies while the Pakistani students felt it was necessary for the completion of their degree programs.

\subsubsection{Instructors' perspectives}

The instructors thought that Afghan students had expectations about the content and teaching methodology of the ECC course. According to one, "They expect that the content should not be too tough, since they had been introduced to English for the first time in Grade 6 which is quite late for introduction of a second/foreign language and they have difficulty in understanding English and its sentence structure." Regarding teaching methodology, they expected the instructor to help them with the exercises given to them or allow them to answer the exercises in groups in class. Secondly, they wanted to have the opportunity to give presentations so that they could score higher marks in speaking skills. But the fact is the main assessments are comprised of writing tests in Pakistani university for this module. Another instructor said that the students talked about their expectations, comparing their English instructors with other instructors.

According to one instructor, Pakistani students do not take allied courses which are other than their core engineering courses seriously. That is why no expectations are shared generally. However, most students wanted to know what the course contents were, their usefulness and the benefits of learning such content. The other instructor was of the view that some students expected the content to be more challenging and demanding. 
They appreciated innovation in teaching methodology and the use of technology for teaching purposes.

One of the instructors said, "Sometimes Afghan students would say, "Why are you teaching reading comprehension passages from an IELTS book?' Although only one or two passages from the IELTS book were given them for practice," said another instructor. The Afghan students' unwillingness to practice IELTS comprehension exercises contrasts with their wish to study abroad in future (See students' perspectivescontent \& methodology). Some students were more concerned with learning accent and presentation skills. "We really want to improve our English, our accent, and presentation skills." Most Afghan students expected their instructors to start with basic grammar and were worried about how to obtain high marks in their assessments.

Table 2 Similarities and differences between ELT methodologies in past and present courses

\begin{tabular}{|c|c|c|c|}
\hline $\begin{array}{l}\text { Afghan Students: } \\
\text { Similarities }\end{array}$ & $\begin{array}{l}\text { Afghan Students: } \\
\text { Differences }\end{array}$ & $\begin{array}{l}\text { Pakistani } \\
\text { Students: } \\
\text { Similarities } \\
\end{array}$ & $\begin{array}{c}\text { Pakistani Students: } \\
\text { Differences }\end{array}$ \\
\hline $\begin{array}{l}\text { - Methods were } \\
\text { same (1) } \\
\text { - English, an } \\
\text { international } \\
\text { language (1) } \\
\text { - Books and methods } \\
\text { are same (1) } \\
\text { - No common } \\
\text { features (7) }\end{array}$ & $\begin{array}{l}\text { - Duration less here (2) } \\
\text { - American accent there, } \\
\text { British here (3) } \\
\text { - Methodology better in } \\
\text { Afghanistan (2) } \\
\text { - In Afghanistan, } \\
\text { instructor allocated } \\
\text { time for different } \\
\text { things e.g. teaching, } \\
\text { listening, reading-one } \\
\text { week for each (1) } \\
\text { - started from the } \\
\text { intermediate, not basic } \\
\text { (1) } \\
\text { - English part of } \\
\text { academic only, not } \\
\text { daily life as compared } \\
\text { to Pakistan (2) } \\
\text { - Focus on grammar in } \\
\text { Afghanistan vs. focus } \\
\text { on vocabulary and } \\
\text { pronunciation in } \\
\text { Pakistan (3) } \\
\text { - Vocabulary } \\
\text { memorization vs. } \\
\text { contextual vocabulary } \\
\text { learning } \\
\text { - A lot of Pashto or Dari } \\
\text { used withmain focus on } \\
\text { grammar (1) }\end{array}$ & $\begin{array}{l}\text { - No similarity } \\
(10)\end{array}$ & $\begin{array}{l}\text { - Simple basic grammar } \\
\text { etc and now advanced } \\
\text { level (2) } \\
\text { - Now we can talk/express } \\
\text { ourselves,focus on } \\
\text { speaking/presentation } \\
\text { skills (2) } \\
\text { - More learning now (1) } \\
\text { - No practice before (1) } \\
\text { - Cramming/rote learning } \\
\text { before, conceptual now } \\
\text { (2) } \\
\text { - were taught grammar, } \\
\text { articles and punctuation } \\
\text { in the past but not in a } \\
\text { detailed way (1) } \\
\text { - No creative writing in the } \\
\text { past (1) } \\
\text { - We were taught like } \\
\text { children. Everything was } \\
\text { made understandable to } \\
\text { us (1) } \\
\text { - Had time for practice. } \\
\text { But now no time for } \\
\text { practice (2) } \\
\text { - are told the way and then } \\
\text { assignment or exercises } \\
\text { are given (1) }\end{array}$ \\
\hline
\end{tabular}




\subsection{Similarities and differences between english language pedagogy: past and present}

As Table 2 shows, all ten Pakistani students and seven Afghan students thought there was no similarity between the way English was taught during their first twelve years of education and the way it is taught at their university at undergraduate level. As for similarities, according to two Afghan students, books/outline and methods are the same. They found them to be the same probably because "English is an international language" as stated by one of them. Students were concerned about the shortage of time and two of them were of the view that in Afghanistan the instructors used to spend a lot of time on each skill, but in Pakistan the time devoted to each skill was too short. This is an inevitable consequence of the fact that in Pakistan they are studying English in a 4 months semester, compared to Afghanistan, where each instructor had a whole year to cover the syllabus and provide students with ample practice in all four skills. However, they believed that in Pakistan, learning/teaching was more conceptual as opposed to the cramming/rote learning in Afghanistan. They were given guidelines for different tasks, such as letter writing and essay writing, but not given enough time to practice. Concerning other differences, the Afghan students pointed out that English was used in daily life in Pakistan, but in Afghanistan, it was required only for academic study/purposes. They wanted the instructors to start with the basics and putmore emphasis on grammar than pronunciation and vocabulary.

All the Pakistani students were also of the view that the teaching content and methods were different from those used in their previous learning institutions. Eight out of ten students said that the university teaching methods were better than the method used in their previous institutions, i.e. school and college. One said, "In some ways, university is better as our linguistic maturation has increased. We have a better education system here." However, they believed that the time was short but also realized that "the instructor is duty bound to cover her syllabus." The students thought that now they had achieved higher level studies in their university, e.g. essay writing and letter writing. Moreover, the pedagogy used was "one step ahead" and there was "more learning". Earlier, there was "no practice or creative tasks". According to one student, there was a "huge difference" since he has now learnt how to express himself "independently through practising presentation skills."Another Pakistani student said, "In the past, we were taught like children. Everything was made understandable to us. We had time for practice. But now, there is no time for practice. We are told the method and then assignments or exercises are given."

Table 3 Effectiveness of ELT methodology: Past or present

\begin{tabular}{|l|l|}
\hline Afghan-Which is better & Pakistani- Which is better \\
\hline - Now better (5) & - Now better (8) \\
- Comprehensive and smooth teaching now (2) & - Great teaching methodology in COMSATS. \\
- General English in Afghanistan vs. field & $\begin{array}{l}\text { Dissatisfied with my past education. No great } \\
\text { access to knowledge (1) }\end{array}$ \\
specific in Pakistan (1) & - Now we can talk. (1) \\
- More concentration on listening, speaking and & - Met my expectations. 3 \\
pronunciation. (2) & - We are studying everything in detail. Now we \\
- Less focus on writing (2) & understand things in a better way. (3) \\
difficult vocabulary used by instructor causes & - Better before (2) \\
- Official language in Pak vs. third language in & - More time and opportunity to read and \\
Afghanistan (1) & understand. Now little time to use our own \\
& ideas to write (2) \\
\hline
\end{tabular}




\subsection{Effectiveness of ELT Pedagogy}

Fifty percent of the Afghan students were of the view that speaking and listening skills are taught in a better way in the Pakistani university. Two of them regarded ELT pedagogy as more "comprehensive and smooth" because the material provided was specific to their field. They liked the idea of using subject specific English in class as they were taught only general English, e.g. grammar, vocabulary and essay writing in their home country. The rest of the students pointed out a limitation in the ELT methodology used in Pakistan as they expected their instructors to lay more emphasis on grammar and writing skills compared to listening, speaking and pronunciation. Three students also pointed out that since the instructors used only English in class, they had difficulty in understanding some of the vocabulary used by them. They wanted the instructors to use easy English in class. This might be due to the different L1s of instructors and students, which could affect their listening and pronunciation skills.

According to eight of the Pakistani students, the teaching methodology used in the university was better than that in the past. Three were pleased with the way everything was taught in detail and made understandable to them. Before, there had been no focus on speaking but now they were able to express themselves. Two students regarded their previous way of being taught better on account of having more time available at their disposal for studying and understanding concepts. Moreover, according to them, before, they were given examples for exam preparation, but now only the rules were explained and they have to attempt tasks and practice themselves.

\subsection{Causes of zero, positive and negative expectations disconfirmation}

Most of the Afghan students mentioned "the university environment", "computers", "internet facility", "multimedia and plantation in the campus" as factors motivating them and contributing to positive disconfirmation and "the experience of learning a new thing each day without any pressure to memorize a lot of vocabulary", "interesting activities" and "practice of presentation skills" as reasons for zero confirmation. Pakistani students, on the other hand, expressed "increased scores in term of percentages", "friendly instructor and classroom environment" as contributing to positive disconfirmation, while high motivation and "increased knowledge", "practice of speaking skills", "vocabulary" and "grammar" and "conceptual learning" were causes of zero confirmation. According to Pakistani students, causes of negative disconfirmation included "tense environment", "consecutive classes without any break in between", "shorter duration", and "instructor not listening to the problems related to the subject" as "she was busy covering the syllabus". They were dissatisfied with the level of theoretical content of the course as they wanted more emphasis on role play and speaking activities compared to grammar and essay or letter writing. The Afghan students also felt the "course content was not clear" and they wanted "less practice in writing and grammar", and that "instructorused advanced level IELTS exercises instead of starting from the basics". They wanted their instructors to focus more on grammar compared to pronunciation, vocabulary and listening skills. The difference in their accent with that of the Pakistani instructors also posed a great problem. However, the students from neither country felt demotivated despite their dissatisfaction, as they said, "I know with time, I will learn" (Afghan student) and "I know we will learn more skills in the advanced modules in the coming semesters" (Pakistani student). According to an Afghan student, "I felt more motivated. You cannot learn everything from the instructor. The instructor only shows you the direction and gives more education." 
Table 4 (a) Pakistani student

causes of negative, zero and positive expectation disconfirmation

\begin{tabular}{|c|c|c|c|c|c|c|c|}
\hline \multicolumn{8}{|c|}{ Pakistani Students } \\
\hline \multicolumn{4}{|c|}{$\begin{array}{c}\text { Causes of Negative Disconfirmation = } \\
\text { Non-fulfillment of expectation }\end{array}$} & \multicolumn{2}{|c|}{$\begin{array}{c}\text { Causes of Zero } \\
\text { Disconfirmation }= \\
\text { Fulfillment of } \\
\text { expectation }\end{array}$} & \multicolumn{2}{|c|}{$\begin{array}{c}\text { Causes of Positive } \\
\text { Disconfirmation = } \\
\text { performance exceeding } \\
\text { expectations }\end{array}$} \\
\hline $\begin{array}{l}\text { Lack of } \\
\text { Practice }\end{array}$ & $\begin{array}{l}\text { Less } \\
\text { improvement } \\
\text { in Speaking } \\
\text { Skills }\end{array}$ & $\begin{array}{c}\text { Content } \\
\text { Irrelevant } \\
\text { to } \\
\text { Practical } \\
\text { Field }\end{array}$ & $\begin{array}{l}\text { Other } \\
\text { Factors }\end{array}$ & $\begin{array}{l}\text { Addition to } \\
\text { Existing } \\
\text { Knowledge }\end{array}$ & $\begin{array}{l}\text { Other } \\
\text { Factors }\end{array}$ & $\begin{array}{l}\text { Improved } \\
\text { Language } \\
\text { Skills }\end{array}$ & $\begin{array}{l}\text { Other factors } \\
\text { (Marks) }\end{array}$ \\
\hline \multirow{3}{*}{$\begin{array}{c}\text { Short } \\
\text { duration } \\
\text { of classes, } \\
\text { unsuitable } \\
\text { for } \\
\text { learning } \\
\text { English } \\
\text { (1) }\end{array}$} & $\begin{array}{l}\text { Less role } \\
\text { plays and } \\
\text { presentations } \\
\text { (1) }\end{array}$ & & \begin{tabular}{|c|} 
Instructor \\
does not listen \\
to our \\
problems \\
related to the \\
subject. (1) \\
\end{tabular} & $\begin{array}{c}\text { Whatever I } \\
\text { wanted from } \\
\text { class (1) }\end{array}$ & $\begin{array}{l}\text { Library, } \\
\text { internet } \\
\text { (1) }\end{array}$ & Speaking(1) & $\begin{array}{l}\text { Get more } \\
\text { marks now } \\
\text { (1) }\end{array}$ \\
\hline & $\begin{array}{c}\text { Focus on } \\
\text { essay and } \\
\text { letter writing } \\
\text { instead of } \\
\text { speaking }(1)\end{array}$ & & $\begin{array}{l}\text { Consecutive } \\
\text { classes (1) }\end{array}$ & & $\begin{array}{l}\text { High } \\
\text { motivation } \\
\text { (3) }\end{array}$ & $\begin{array}{c}\text { Vocabulary (1) } \\
\text { comprehension } \\
\text { (1) Creative } \\
\text { writing (1) }\end{array}$ & $\begin{array}{l}\text { Friendly } \\
\text { classroom } \\
\text { environment } \\
\text { (4) }\end{array}$ \\
\hline & & & $\begin{array}{c}\text { Tense } \\
\text { environment } \\
(1)\end{array}$ & & & $\begin{array}{c}\text { Current } \\
\text { knowledge } \\
\text { more that in the } \\
\text { previous (1) }\end{array}$ & \\
\hline
\end{tabular}

Table 4 (b)Afghan Students:

Causes of Negative, Zero and Positive Expectations Disconfirmation

\begin{tabular}{|c|c|c|c|c|c|c|c|}
\hline \multicolumn{8}{|c|}{ Afghan Students } \\
\hline \multicolumn{3}{|c|}{$\begin{array}{c}\text { Causes of Negative } \\
\text { Disconfirmation }\end{array}$} & \multicolumn{3}{|c|}{$\begin{array}{c}\text { Causes of Zero Disconfirmation }= \\
\text { Confirmation }\end{array}$} & \multicolumn{2}{|c|}{$\begin{array}{l}\text { Causes of Positive } \\
\text { Disconfirmation }\end{array}$} \\
\hline \multirow{6}{*}{$\begin{array}{c}\text { American } \\
\text { vs } \\
\text { British } \\
\text { Accent } \\
\text { (1) }\end{array}$} & $\begin{array}{l}\text { Less focus } \\
\text { on basics }(2)\end{array}$ & \begin{tabular}{|c|} 
English- \\
sole \\
medium \\
of \\
instruction \\
$(1)$ \\
\end{tabular} & $\begin{array}{c}\text { Hot } \\
\text { weather } \\
(4)\end{array}$ & $\begin{array}{c}\text { Good } \\
\text { Activities }\end{array}$ & $\begin{array}{c}\text { Learnt } \\
\text { something new } \\
\text { every day (1) }\end{array}$ & $\begin{array}{c}\text { skills having a } \\
\text { good influence on } \\
\text { our study (1) }\end{array}$ & $\begin{array}{l}\text { Internet, } \\
\text { computers, } \\
\text { multimedia } \\
\text { related } \\
\text { facilities(4) }\end{array}$ \\
\hline & $\begin{array}{c}\text { Learnt } \\
\text { nothing } \\
\text { special(1) } \\
\end{array}$ & & $\begin{array}{l}\text { No new } \\
\text { things } \\
\text { learnt (2) }\end{array}$ & $\begin{array}{l}\text { Exercises } \\
\text { were } \\
\operatorname{good}(1) \\
\end{array}$ & $\begin{array}{l}\text { How to speak } \\
\text { in different } \\
\text { situations }(1) \\
\end{array}$ & $\begin{array}{c}\text { English speaking } \\
\text { environment all } \\
\text { the time(1) }\end{array}$ & $\begin{array}{l}\text { Greenery, } \\
\text { trees(2) }\end{array}$ \\
\hline & $\begin{array}{c}\text { Course } \\
\text { contents not } \\
\text { clear (1) }\end{array}$ & & & $\begin{array}{l}\text { Presentations } \\
\text { (2) }\end{array}$ & $\begin{array}{l}\text { No pressure of } \\
\text { learning a } \\
\text { bundle of } \\
\text { vocabulary or } \\
\text { grammar in a } \\
\text { day(1) }\end{array}$ & & $\begin{array}{l}\text { Good } \\
\text { campus }(1)\end{array}$ \\
\hline & $\begin{array}{l}\text { Less writing } \\
\text { practice (1) }\end{array}$ & & & & & & $\begin{array}{l}\text { Environment } \\
\text { of this } \\
\text { university(1) }\end{array}$ \\
\hline & & & & & & & $\begin{array}{l}\text { Educated } \\
\text { people(1) }\end{array}$ \\
\hline & $\begin{array}{l}\text { Didn't learn } \\
\text { much } \\
\text { grammar(1) }\end{array}$ & & & & & & $\begin{array}{c}\text { Educational } \\
\text { environment } \\
\text { (1) }\end{array}$ \\
\hline
\end{tabular}




\section{DISCUSSION AND CONCLUSION}

The present study reveals that most of the Afghan and Pakistani students interviewed expected to improve their speaking and creative writing skills through the ECC course but their expectation had negative disconfirmation. However, they admitted that at their present institution, there was more emphasis on speaking and writing skills compared to their previous education but more time was necessary/needed to bring about significant improvement. In line with the results of previous study of students' expectations (Bordia et. al. 2006, 4.14), the current study also found that the lack of fulfillment of students' expectations led to behavioural and performance related issues. The instructors felt that the Afghan students became aggressive and agitated when they did not get the desired results. However, this did not result in student attendance dropping, as is usually the outcome of unmet expectations (Lobo \& Gurney 2014, 748). Most Afghan students were disturbed and dissatisfied because they expected their instructors to start from the level of basic grammar and wanted more time to be given to each language skill. Both Pakistani and Afghan students complained that one semester was too short to polish up their language skills. This was probably because they were studying in the semester system for the first time.

Unlike the findings of Bordia et al., (2006, 4.15), neither Afghan or Pakistani students felt demotivated about learning English as they believed that they would gradually improve. Moreover, Bordia et. al.'s study subjects were learning English for professional success, while the main concern of the students in this studywas academic success. Both groups of students, especially the Afghans, were concerned about their performance as their parents could also check their grades online. In addition, they agreed that English is important for academic and professional success; therefore, there was no instance of course withdrawal.

The current study also reinforces the findings of the study based on Afghan immigrants in Canada (Nazar 2012, 36) which revealed that Afghan students' weakest areas were listening and speaking skills. Most students suggested more emphasis should be laid on speaking skills, but they did not show much interest in improving them.

The groups differed in their expectations of the emphasis on grammar. As there was more emphasis on grammar in Afghanistan, Afghan students wanted to be taught along the same lines in Pakistan, while Pakistani students expected to have more emphasis on fluency in speaking and creative writing. Afghan students linked their learning English to the long term goals of higher education, i.e. Masters abroad, whereas Pakistani students wanted their tasks to be linked to their major, i.e. Engineering.

Most Pakistani students were satisfied because there was more focus on conceptual learning as compared to cramming. They were also happy with the provision of facilities like the internet and library, etc. The friendly environment and positive attitude of classmates also led to enhanced satisfaction. The facilities and learning environment were also major factors causing the positive disconfirmation of the Afghan students' expectations.

Keeping in view both groups' expectations and their respective goals in learning English, this study recommends teaching both Afghan and Pakistani students through a Task Based Language Teaching (TBLT) methodology inspired by Dewey's (1913) focus on the importance of experience and 'intelligent effort' for effective learning along with Communicative Language Teaching (CLT) methodology. The effectiveness of TBLT can be enhanced if the tasks are contextualized in consideration of the cultural background of the learners. Therefore, this study recommends the use of Contextualized Task-based 
Language Teaching (CTBLT) in combination with Input-oriented approach (Lee \& Van Patten, 2003) as improvement in foreign language proficiency requires input from the instructor in the form of both classroom activities and home assignments. Based on the needs of the students studied, tasks for Afghan students need more 'focus on form', while those for Pakistani students need more 'focus on content,' as proposed by Ellis (2009).

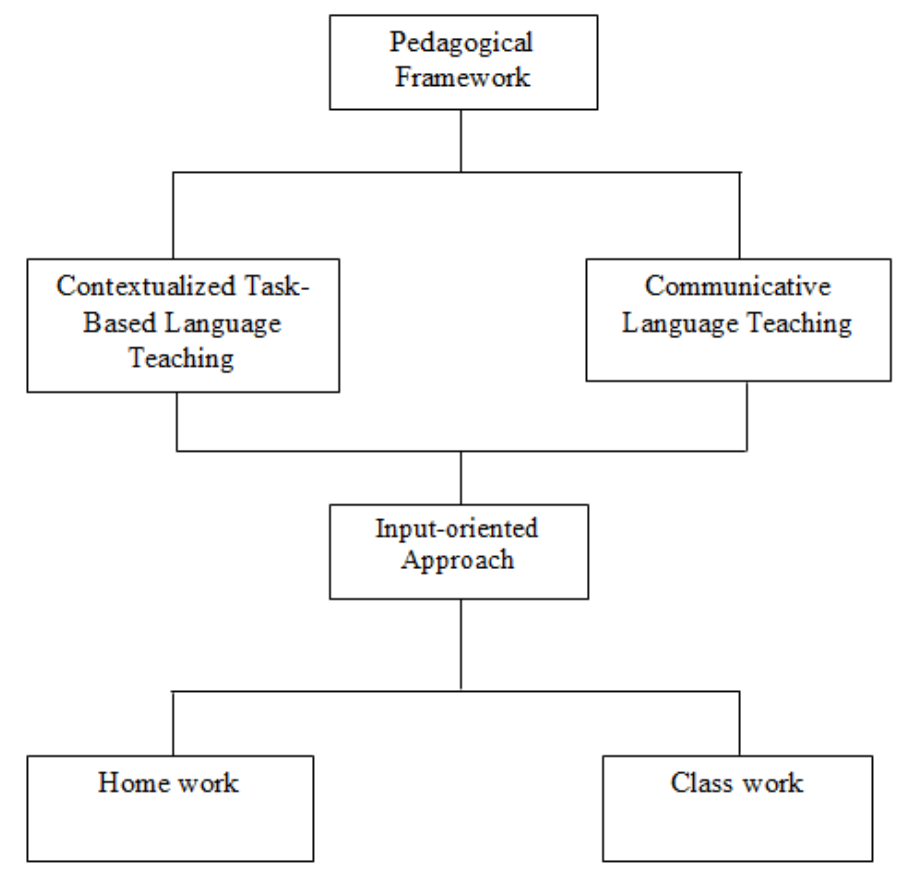

Fig. 2 Proposed pedagogical framework for ESL instructors teaching culturally diverse students

In the case of Afghan and Pakistani students, form and content can have emphasis in accordance with their needs, even though syntax and meaning are equally important and therefore cannot be separated. Content and contextualized tasks for both groups need to be as linked to the majors they are studying as possible so they can relate to them and take more interest in the module and the learning process. Cultural competence on the part of the instructors can help them design tasks for the students keeping in mind their socio-cultural contexts.

The content introduced to Afghans needs to be simpler at the beginning and progressively turned into more advanced and complex, keeping in view their performance development and achievement. In addition, the students' autonomy needs to be considered and they need to be encouraged to do further research and reading outside the classroom in order to make greater improvement in their performance.

Instructors teaching English language are also recommended to conduct a needs analysis before starting each course and collaborate with the instructors teaching their undergraduate majors so they can decide mutually what type of skills, instruction and support they need from ELT instructors. Refresher courses and task based ideas-sharing 
meetings of instructors are also suggested for building instructor capacity to cater for learner diversity.

More use of technology and ample amount of input introduction for its use is also suggested, keeping in view students' expectations for more practice and dissatisfaction/ negative disconfirmation concerning the short time available in a semester. The system also needs to revise the timetable to ensure breaks between each two consecutive classes. To compensate for the limited time available, homework based reading tasks and practice exercises are suggested. Students' learning strategies need to develop. Instructors can guide them by giving them task-based reading assignments and homework so they have exposure to sufficient amount of input in the 4 months limited time period of a semester, which allows for only 32 contact hours with instructors in which they have to teach all four skills and grammar, which leaves room for the introduction of a limited amount of input. If however, all four skills, grammar and vocabulary, are taught through task based teaching, the instructors can introduce students to as much written and spoken input as possible if tasks are designed intelligently. Secondary schools also need to prepare students for conceptual learning, technology based learning and listening and speaking skills need to be added to the syllabus at tertiary level.

It is strongly recommended that every instructor teaching an ESL course should conduct similar interview/surveys regarding students' expectations along with a diagnostic test of learners' overall proficiency levels for a proper needs analysis at the start of the course in order to select the appropriate teaching methodology and focus for teaching.

\section{REFERENCES}

Badstübner, Tina, and Peter Ecke. "Student expectations, motivations, target language use, and perceived learning progress in a summer study abroad program in Germany." Die Unterrichtspraxis/Teaching German 42, no. 1 (2009): 41-49. http://www.jstor.org/stable/ 40608587

Bordia, Sarbari, Lynn Wales, Jeffery Pittam, and Cindy Gallois. "Student expectations of TESOL programs." Australian Review of Applied Linguistics 29, no. 1 (2006): 4-1.DOI: 10.2104/aral0604.

Bordia, Sarbari, Lynn Wales, Cindy Gallois, and Jeffery Pittam. "Antecedents and consequences of TESOL student expectations." Australian Review of Applied Linguistics 31, no. 2 (2008): 15-1.

Dewey, John. Interest and effort in education. Houghton Mifflin, 1913.

Dörnyei, Zoltán. The psychology of the language learner: Individual differences in second language acquisition. Routledge, 2014.

Ellis, Rod. "Task- based language teaching: Sorting out the misunderstandings." International journal of applied linguistics 19, no. 3 (2009): 221-246.

Goldschmidt, Myra M., and Thomas Seifried. "Mismatched expectations among developmental ESL students in higher education." Research and Teaching in Developmental Education (2008): 27-38.

Hassel, Stefanie, and Nathan Ridout. "An Investigation of First-Year Students' and Lecturers' Expectations of University Education." Frontiers in psychology 8 (2018): 2218.

Hsieh, Hsiu-Fang, and Sarah E. Shannon. "Three approaches to qualitative content analysis." Qualitative health research 15, no. 9 (2005): 1277-1288. 
Iwaniec, Janina. "The effects of parental education level and school location on language learning motivation." The Language Learning Journal (2018): 1-15. DOI:10.1080/ 09571736.2017.1422137

Lasagabaster, David. "English achievement and student motivation in CLIL and EFL settings." Innovation in language Learning and Teaching 5, no. 1 (2011): 3-18. DOI:10.1080/17501229.2010.519030

Lehmann, Wolfgang. "University as vocational education: working- class students' expectations for university." British Journal of Sociology of Education 30, no. 2 (2009): 137-149. DOI:10.1080/01425690802700164

Lobo, Ana, and Laura Gurney. "What did they expect? Exploring a link between students' expectations, attendance and attrition on English language enhancement courses." Journal of Further and Higher Education 38, no. 5 (2014): 730-754. DOI:10.1080/0309877X. 2013.817002

Masgoret, A- M., and Robert C. Gardner. "Attitudes, motivation, and second language learning: A meta- analysis of studies conducted by Gardner and associates." Language learning 53, no. S1 (2003): 167-210.

Money, Julie, Sarah Nixon, Fran Tracy, Claire Hennessy, Emma Ball, and Track Dinning. "Undergraduate student expectations of university in the United Kingdom: What really matters to them?." Cogent Education 4, no. 1 (2017): 1301855.

Ganyaupfu, Elvis Munyaradzi. "Factors influencing academic achievement in quantitative courses among business students of private higher education institutions." Journal of Education and Practice 4, no. 15 (2013): 57-65. http://journalofbusiness.org/index.php/ GJMBR/article/view/721

Nawaz, Humera, Muhammad Amin, and Ijaz Ahmed Tatla. "Factors Affecting Students' Motivation Level to Learn English as a Second Language in the Pakistani University Context." Journal of Research \& Reflections in Education (JRRE) 9, no. 2 (2015). http://www.ue.edu.pk/jrre

Nazar, Khesraw E. "Opportunities And Challenges: Afghan Youth Learning English."http://digital.library.ryerson.ca/islandora/object/RULA:1773/datastream/OBJ /download/Opportunities_And_Challenges_Afghan_Youth_Learning_English.pdf

Ngo, Huong, Rebecca Spooner-Lane, and Amanda Mergler. "A comparison of motivation to learn English between English major and non-English major students in a Vietnamese university." Innovation in Language Learning and Teaching 11, no. 2 (2017): 188-202. DOI:10.1080/17501229.2015.1094076

Oliver, Richard L. "A cognitive model of the antecedents and consequences of satisfaction decisions." Journal of marketing research 17, no. 4 (1980): 460-469. http://www.jstor. org/stable/3150499

Oliver, Richard L. Satisfaction: A behavioral perspective on the consumer: A behavioral perspective on the consumer. Routledge, 2014.

Paechter, Manuela, Brigitte Maier, and Daniel Macher. "Students' expectations of, and experiences in e-learning: Their relation to learning achievements and course satisfaction." Computers \& education 54, no. 1 (2010): 222-229.

Palys, Ted. "Purposive sampling." In The Sage encyclopedia of qualitative research methods, 697-8. Edited by Lisa M. Losa Angeles: Sage Publications, 2008. 
Rahman, Tariq. "Language policy, multilingualism and language vitality in Pakistan." LesserKnown Languages of South Asia: Status and Policies, Case Studies, and Applications of Information Technology (2003): 73-104. http://www.sil.org/asia/ldc/parallel_papers/ tariq_rah man.pdf.

Raza, Irfan, S. "Govt grants scholarships to 3,000 Afghan students." Dawn, February 09, 2017. https://www.dawn.com/news/1313661

Sander, Paul, Keith Stevenson, Malcolm King, and David Coates. "University students' expectations of teaching." Studies in Higher education 25, no. 3 (2000): 309-323. DOI: 10.1080/03075070050193433

Shah, Syed, K., and Afsar, Ayaz."Repositioning English language in Pakistan in the context of globalization."Journal of Social Sciences 8,no. 2 (2017): 160-179.

Song et al. "The Effects of Expectation Disconfirmations on Customer Outcomes in EMarkets: Impact of National Culture." Journal of Marketing Channels 23, no. 4 (2016): 217-229. DOI: 10.1080/1046669X.2016.1224305

Sugita, Maya, and Osamu Takeuchi. "What can teachers do to motivate their students? A classroom research on motivational strategy use in the Japanese EFL context." Innovation in Language Learning and Teaching 4, no. 1 (2010): 21-35. DOI: 10.1080/ 17501220802450470

Tremblay, Paul F., R. C. Gardner, and GerwinHeipel. "A model of the relationships among measures of affect, aptitude, and performance in introductory statistics." Canadian Journal of Behavioural Science/Revue canadienne des sciences du comportement 32, no. 1 (2000): 40.

Wang, Shu-Tai, and Cheng-Chung Chen. "Path Analysis on the Factors Influencing Learning Outcome for Hospitality Interns--From the Flow Theory Perspective." Journal of Education and Learning 4, no. 3 (2015): 25-44. DOI: http://dx.doi.org/10.5539/jel. $\mathrm{v} 4 \mathrm{n} 3 \mathrm{p} 25$

Zaynal, Jamshid,Mushtaq, Nematullah, S., andKazimi, Frishta. English for Afghanistan Student's book (Grade 8). Ministry of Education. Islamic Republic of Afghanistan, 2011. 